\title{
Self-esteem and psychopathology in the children with Type 1 diabetes
}

\author{
Tip 1 diyabetli çocuklarda benlik saygısı ve psikopatoloji
}

\author{
Ayla Uzun*, Emine Çı̆̆ıl Fettahoğlu, Şeref Şimşek, Erdem Durmaz, İffet Bircan
}

Child and Adolescent Mental Health and Diseases Clinic (A. Uzun, MD), Recep Tayyip Erdogan University Education and Research Hospital, TR-53000 Rize, Department of Child Psychiatry (Assist. Prof. E. Ç. Fettahoğlu, MD), Department of Pediatric Endocrinology (Prof. İ. Bircan), Akdeniz University Medicine of School, TR-07059 Antalya, Department of Child Psychiatry (Assist. Prof. Ş. Şimşek, MD), Dicle University Oncology Hospital, TR-21300 Diyarbakır, Department of Pediatric Endocrinology (E. Durmaz, MD), Mersin State Hospital, TR-33050 Mersin

\begin{abstract}
Aim. This study aims to evaluate psychiatric disorders and self-esteem in children with Type 1 diabetes mellitus (Type 1 DM). Methods. The study enrolled 52 volunteer children aged between 8 and 12-years-old, who have been diagnosed with Type $1 \mathrm{DM}$, and "group with psychiatric disease" (PG) $(n=28)$ and "healthy controls" (HC) $(n=26)$ consisted of healthy controls who are age- and sex-matched with patient group. Sociodemographic data were obtained using standard sociodemographic data collection form. The children were administered semi-structured diagnostic interview (K-SADS-PL), Piers-Harris children's self-concept scale (PHCSCS) and Rosenberg Selfesteem Scale (RSES). Results. It was observed that $59.6 \%$ of the children with DM $(n=31)$ still had at least one psychiatric disorder. It was seen that, in the diabetic group, HbA1C levels were higher in those with psychiatric disorder compared to those without it $(\mathrm{p}=0.024)$. It was found that self-esteem of the children in the group with psychiatric disorder was lower compared to both healthy counterparts $(\mathrm{p}=0.00)$ and the children with $\mathrm{DM}(\mathrm{p}=0.005)$. It was found that the children in the group with psychiatric disorder had lower self-esteem compared to healthy counterparts. When self-concept of the children was examined, it was seen that there was a difference across the groups $(\mathrm{p}=0.02)$, which was attributed to more negative self-concepts of the children with DM compared to healthy counterparts $(\mathrm{p}=0.04)$. In the children with $\mathrm{DM}$, it was seen that interpersonal relation problems were seen in a wider range of areas. Conclusion. It is seen that, in the children with Type I DM, self-concept was more negative compared to healthy children, that problems in relation were seen in a wider range of areas and that the presence of a psychiatric disease increased HbA1C levels. These results suggest that psychiatric evaluation is required during the follow-up of the diabetic children, allowing the recognition and treatment of eventual psychopathologies and the prevention of the eventual complications that may develop in the future.
\end{abstract}

Keywords: Type I Diabetes Mellitus, child, psychopathology, self-esteem

\section{Özet}

Amaç. Bu çalışmada Tip 1 Diyabetes Mellituslu (Tip 1 DM) çocuklarda psikiyatrik sorunlar ve benlik saygısının değerlendirilmesi amaçlanmıştır. Yöntem. Çalışmaya Tip 1 DM tanılı 8-12 yaş arasında 52 gönüllü çocuk ile sağlıklı gönüllülerden oluşan, hasta grubuyla yaş ve cinsiyet açısından eşleştirilmiş "psikiyatrik hastalığı olan grup" (PG) (n=28) ve "sağlıklı kontroller" (SK) $(n=26)$ alındı. Sosyodemografik veriler standart sosyodemografik veri toplama formu ile elde edildi. Çocuklara yarı yapılandırılmış tanı görüşmesi (K-SADS-PL), Piers-Harris Çocuklarda ÖzKavramı Ölçeği (PHÖKÖ), Rosenberg Benlik Saygısı Ölçeği (RBSÖ) uygulandı. Bulgular. DM'li çocukların \%59,6'sında ( $=31)$ en az bir psikiyatrik bozukluğun olduğu saptandı. Diabetik grupta psikiyatrik bozukluğu olanların HbA1C düzeylerinin olmayanlardan daha yüksek $(\mathrm{p}=0,024)$ olduğu görüldü. Psikiyatrik bozukluk grubundaki çocukların benlik saygılarının hem sağlıklı yaşıtlarından $(\mathrm{p}=0,00)$ hem de DM'lilerden $(\mathrm{p}=0,005)$ daha düşük olduğu saptandı. Çocukların öz kavramlarına bakıldığında ise gruplar arasında farklılık olduğu $(p=0,02)$ ve bunun DM'li çocukların sağlıklı yaşıtlarına göre özkavramlarının daha olumsuz olmasına bağlı olduğu görüldü $(p=0,04)$. DM'li çocuklarda kişilerarası ilişki sorunlarının daha yaygın alanlarda görüldüğü 
bulunmuştur. Sonuç. Tip I DM'li çocukların öz kavramlarının sağlıklı çocuklardan daha olumsuz olduğu, kişilerarası ilişki sorunlarının daha yaygın alanlarda görüldüğü ve psikiyatrik bir hastalık varlığında HbA1C düzeyini de arttığı görülmektedir. Bu sonuçlar diyabetli çocukların takipleri sırasında psikiyatrik değerlendirmenin yapılmasının gerekli olduğunu, böylece olası psikopatolojilerin tanınarak tedavisi edilmesi ve ileride gelişebilecek olası komplikasyonların önlenebileceğini düşündürmektedir.

Anahtar sözcükler: Tip 1 Diyabetes Mellitus, çocuk, psikopatoloji, benlik saygısı

Geliş tarihi/Received: November 18, 2014; Kabul tarihi/Accepted: December 02, 2014

\section{*Corresponding author:}

Dr. Ayla Uzun, Çocuk ve Ergen Ruh Sağlığı ve Hastalıkları Kliniği, Recep Tayyip Erdoğan Üniversitesi Eğitim ve Araştırma Hastanesi. TR-53000 Rize. E-mail: dr.f.ayla@ hotmail.com

*All parents gave informed written consent and the children gave consent. The study was approved by Akdeniz
University, Human Trial Ethic Board according to the Declaration of Helsinki.

\section{Introduction}

Diabetes Mellitus (DM) is the disorder of carbohydrate, lipid and protein metabolisms resulting from a lack of insulin release or efficacy [1]. Type I DM is one of the most common chronic diseases during childhood and affects one of each 400 individuals aged below 20 years-old [2]. Model recommended for the treatment of Type I diabetes is a complex, time-consuming and labouring method that requires frequent monitoring of the blood sugar level (at least 4 times per day), control and monitoring of the carbohydrate intake, the administration of insulin for 3-4 days daily and adjustment of the insulin dose according to nutrition and activity types [3]. Adherence to these intensive therapeutic requirements is cumbrous, boring and stressing for the child and for the mothers, who are the main people responsible for the treatment, and leads to a burden on the child and on the familial relations [4].

As DM affects the life of the child by all aspects [5], it is specified that these children show an incidence of psychiatric disorder 2-3 fold higher than healthy counterparts [6]. In the longitudinal studies conducted on the children with Type I DM, it was reported that 1year and lifetime prevalence of the psychiatric disorder were 47\% [7] and 37\% [5], respectively, and that most commonly reported disorders were internalizing problems (depression and anxiety) or externalizing problems (impulsivity, hyperactivity and aggression) $[5,8]$.

In diabetic children, the presence of psychiatric problems complicates the compliance to the treatment for diabetes, impairs the metabolic control and increases the hospitalization $[5,9]$. Haemoglobin A1C (HbA1C) level, which is considered to be an indicator of the metabolic control, was found to be significantly higher in the DM patients with psychiatric disorder compared to those without psychiatric disorder $[9,10]$. It was stated that the children and the adolescents with a poor metabolic control could more commonly have depression and anxiety disorders and could experience psychosocial, emotional and behavioral difficulties such as lower self-esteem [11].

It was suggested that the chronic diseases seen during the childhood could prevent the developmental gains appropriate for the age of the children and could affect body perception, self-concept and self-esteem [12]. It was demonstrated that the adolescents with good metabolic control had lower anxiety levels and more favourable self-concept [13]. While self-concept defines feelings, perceptions, believes and insights of an individual about him/herself, self-esteem is defined as feeling him-/herself as proud, precious, efficient and successful and shows how an individual evaluates him-/herself 
[14]. The structures such as self-esteem and self-concept are personal sources that facilitate positive evaluation of the stressful life events and that reduce psychological strain [15]. It was demonstrated that diabetic children and adolescents had lower selfesteem, leading to impairment in the therapeutic compliance [16]. This study aims to compare self-esteem, self-concept and psychopathologies between the children with and without psychiatric disorder among the children with Type $1 \mathrm{DM}$. It was hypothesized that that diabetic children and adolescents have more psychopathology and lower selfesteem than the comparison group.

\section{Material and method}

The study included a study group consisted of a total of 52 volunteer children aged between 8 and 12 years-old who have been followed-up for at least 1 year with the diagnosis of Type I DM in Akdeniz University School of Medicine, Polyclinic of Pediatric Endocrinology Department. Mental retardation, common developmental disorders during the interview, mania or psychotic disorders or another medical disease except diabetes were among exclusion criteria.

Control group was formed by putting an advertisement within the hospital and 54 ageand sex-matched volunteer children without any medical disease and mental developmental retardation were selected. After the examinations of mental status and semi-structured interviews in the clinic, control group was subdivided into two groups as "group with psychiatric disease" (PG) (n=28) and "healthy controls" (HC) (n=26).

\section{Data collection tools}

\section{Sociodemographic data form}

It includes demographics such as age, gender, educational status, interpersonal relations and familial characteristics. In addition, disease information such as duration of the diabetes, treatment status, HbA1C level and the presence of complication were obtained from the patient group.

\section{Piers-Harris children's self-concept scale (PHCSCS)}

It is a self-reporting scale that evaluates the feelings, the thoughts and the attitudes of the children towards themselves. It was developed for the age group of 7-18 years by Piers and Harris [17] and the validity and the reliability of its Turkish version were evaluated by Öner and Çataklı $[18,19]$. The scale was consisted of 80 descriptive items that were answered as "yes" or "no". The scores obtained accordingly vary between 0 and 80 . In our study, we used the total score. Reliability of the Turkish form varied between 81 and 89. It is considered to be valid and reliable for the measurement of the psychological health in the children. Cronbach's alpha ratio was 0.73-0.92. Higher score indicates a positive self-concept and lower score indicates a negative self-concept.

\section{Rosenberg self-esteem scale}

This scale that was developed by Rosenberg [13] was adapted to our country by Çuhadaroğlu [20]. Validity coefficient was 71 and reliability coefficient was 75 . This scale consisting of 63 articles included 12 subtests. In this study, a self-esteem subtest consisting of only 10 items, which measured positive and negative aspects of the selfesteem, was used. Internal reliability (Cronbach's alpha) was 0.60 . higher scores indicate positive self-esteem.

\section{Schedule for affective disorders and schizophrenia for school-age children present and lifetime version (sads-pl: $k$-sads-pl)}

SADS-PL is a semi-structured diagnostic interview that was developed to detect previous and current psychopathologies according to DSM-III and DSM-IV diagnostic criteria in the children and in the adolescents [21]. In the Turkish sample, validiaty and reliability study was performed by Gökler et al. [22]. SADS-PL is performed by interviewing with parents and child and, finally, by doing an evaluation based on the information obtained from all sources. 


\section{Statistical analysis}

For the statistical analyses, SPSS for Windows Ver. 17.0 (SPSS Inc., IL, USA) was used. In order to test whether there was a quantitative difference between two independent groups, chi-square $\left(\mathrm{X}_{2}\right)$ test was used for non-parametric values and t test was used for continuous numbers. In the evaluations of three groups, one-way ANOVA test, KruskalWallis ranked one-way ANOVA test and Multiple Comparison Test (Post-hoc Scheffe test) were done. In order to determine the direction and the level of the relation between the variables, Pearson correlation analysis was used. The interpretation of the results was based significance level of 0.05 .

\section{Results}

Demographic data belonging to the children enrolled in the study are presented in Table 1. Accordingly, three groups (DM, PG, HC) were similar in terms of gender distribution, age, education, body mass index (BMI) and the age of the parents $(\mathrm{p}>0.05)$. When the educational levels of the parents were examined, it was found that both mothers and fathers of the children from PG and HC groups had similar educational levels and higher educational levels compared to those of the children with $\mathrm{DM}(\mathrm{p}=0.00$ and $\mathrm{p}=0.03$, respectively).

Table 1. Demographic characteristics of the subjects.

\begin{tabular}{llll}
\hline & DM $(\mathbf{N}=\mathbf{5 2})$ & PG $(\mathbf{N}=\mathbf{2 8})$ & HC $(\mathbf{N}=\mathbf{2 6})$ \\
\hline Gender (male/female) (\%) & $29 / 23(55.8 / 44.2)$ & $15 / 13(53.6 / 46.4)$ & $15 / 11(55.7 / 42.3$ \\
Age (year) & $9.8 \pm 1.4$ & $9.7 \pm 1.4$ & $9.7 \pm 1.4$ \\
Education (year) & $4.4 \pm 1.5$ & $4.5 \pm 1.4$ & $4.6 \pm 1.4$ \\
Body Mass Index & $18.2 \pm 2.9$ & $19.2 \pm 4.3$ & $18.7 \pm 3.3$ \\
Maternal age (year) & $38.0 \pm 7.4$ & $35.5 \pm 4.4$ & $37.6 \pm 4.8$ \\
Maternal educational level (year)* & $7.1 \pm 2.9$ & $8.8 \pm 4.1$ & $11.1 \pm 4.0$ \\
Paternal age (year) & $41.9 \pm 7.5$ & $40.2 \pm 4.4$ & $40.4 \pm 3.5$ \\
Paternal educational level (year)** & $8.4 \pm 3.1$ & $10.0 \pm 4.3$ & $11.4 \pm 3.9$ \\
\hline
\end{tabular}

DM: Type 1 diabetes mellitus, PG: Group with psychiatric disease, HC: Healthy controls, *: One-way ANOVA F= 11.1; $p=0.00$; post hoc Scheffe test HC $>$ DM $(p=0.00 ; * *: F=6.3 ; p=0.03$ HC $>$ DM $p=0.03)$

The children in DM, PG and HC groups were questioned about how they achieved the school success levels and whether they experienced problems in their social relations and the results were presented in Table 2. Data were firstly examined using Kruskal Wallis test and, for the results that were found to be significant, the groups were compared using $\mathrm{X}_{2}$ test and the group from which the difference was originating was detected. Groups were found to be different in terms of the level of achievement of the children in the school (good, average and bad). This difference is explained by the fact that healthy children had a higher incidence of "good" school achievement compared to both the children with DM $\left(\mathrm{X}_{2}=6.7 ; \mathrm{p}=0.03\right)$ and those with PG $\left(\mathrm{X}_{2}=8.5 ; \mathrm{p}=0.01\right)$. It was seen that the children with $\mathrm{DM}$ and psychiatric disorder provided similar descriptions of school achievements $\left(\mathrm{X}_{2}=1.49 ; \mathrm{p}>0.05\right)$.

Table 2. The problems described by the children.

\begin{tabular}{|c|c|c|c|c|}
\hline & DM n=52 (\%) & PG $n=28(\%)$ & HC n=26 (\%) & p \\
\hline \multicolumn{5}{|l|}{ School achievement } \\
\hline Good & $37(71.2)$ & $18(64.3)$ & $25(96.2)$ & $0.016^{*}$ \\
\hline Average & $11(21.2)$ & $9(32.1)$ & $1(3.8)$ & \\
\hline $\mathrm{Bad}$ & $4(7.7)$ & $1(3.6)$ & & \\
\hline \multicolumn{5}{|l|}{ Social relations } \\
\hline Problems with friends & $18(34.6)$ & $5(17.9)$ & $1(3.8)$ & $0.008^{*}$ \\
\hline Problems with opposite sex & $20(38.5)$ & $10(35.7)$ & $2(7.7)$ & $0.016^{*}$ \\
\hline Problems with parents & $20(38.5)$ & $14(50)$ & $2(7.7)$ & $0.003 *$ \\
\hline Problems in other relations & $15(28.8)$ & $2(7.1)$ & $1(3.8)$ & $0.006^{*}$ \\
\hline
\end{tabular}


When the perception of the children enrolled about the social relations was examined, it was found that the rate of the children with $\mathrm{DM}$ who experienced problems in their relations with their friends $(\mathrm{p}=0.004)$, opposite $\operatorname{sex}(\mathrm{p}=0.007)$, their parents $(\mathrm{p}=0.007)$ and other people $(\mathrm{p}=0.02)$ was higher compared to their healthy counterparts. In addition, among these children, the rate of those who experienced problem in their relations with other people such as teachers and relatives was higher compared to those with PG $(\mathrm{p}=0.004)$.

In the children with psychiatric disease, the rate of the children who experienced problems with opposite sex $(\mathrm{p}=0.03)$ and with their parents $(\mathrm{p}=0.0007)$ was higher among those with psychiatric disease compared to healthy counterparts (Table 2). When the selfconcept of the children was examined, it was seen that there was a difference across the groups ( $\mathrm{p}=0.02)$ and this difference resulted from more negative self-concept observed in the children with DM compared to healthy controls $(\mathrm{p}=0.04)$. Self-esteem scores obtained from RSES exhibited differences across the groups $(\mathrm{p}=0.00)$ and this was found to be related to lower self-esteem observed in the children with psychiatric group compared to both healthy counterparts $(\mathrm{p}=0.00)$ and those with $\mathrm{DM}(\mathrm{p}=0.005)$ (Table 3$)$.

Current psychopathologies of all children were evaluated using K-SADS and the results were presented in Table 3. It was seen that $59.6 \%$ of the children with DM $(n=31)$ still had at least one psychiatric disorder. Of the children with DM, 23 (44.2\%) had one, 6 (35\%) had 2 and $2(3.8 \%)$ had two psychiatric disorders. In the psychiatric group, 17 $(60.7 \%)$ had one and $11(39.3 \%)$ had 2 psychiatric disorders. When the groups with DM and PG were compared in terms of the distribution of psychiatric disorders detected in the children during the study, the incidences of depression $(\mathrm{p}=0.03)$ and elimination disorders $(\mathrm{p}=0.00004)$ were significantly higher in the patients with PG. When the correlation between psychiatric diagnosis and gender was examined, it was found that the incidence of psychopathology was higher in the male diabetic children compared to female diabetic children $[\mathrm{n}=21(72.4 \%)$ and $\mathrm{n}=10(43.5 \%)$, respectively] $(\mathrm{p}=0.048)$ and that the group with PG showed similar incidence rates of psychopathology in both gender $[50 \%(n=15)$ in males, $54.2 \%(\mathrm{n}=13)$ in females].

In the children with $\mathrm{DM}$, mean duration of disease was $4.2(\mathrm{sd}=2.2)$ years and mean HbA1c level was 8.7 ( $\mathrm{sd}=1.6$ ). No statistically significant difference of mean number of hospitalization was found between the diabetic children with psychiatric disorders and those without diagnosis $(\mathrm{t}=-0.9 ; \mathrm{df}=45.5 ; \mathrm{p}=0.4)$

Table 3. Results for self-concept, self-esteem and psychopathology.

\begin{tabular}{|c|c|c|c|c|}
\hline & $\mathrm{DM} \mathrm{N}=52(\%)$ & PG n=28 (\%) & $\mathrm{HC} \mathrm{N}=26(\%)$ & $\mathbf{p}$ \\
\hline $\mathrm{PHCSCS}^{\#}$ & $62,4 \pm 10.6$ & $62.1 \pm 8.5$ & $68.2 \pm 7.5$ & \\
\hline RSES \#\# & $21.8 \pm 4.8$ & $18,4 \pm 3.0$ & $23.2 \pm 4.3$ & $>0.05^{*}$ \\
\hline \multicolumn{5}{|l|}{ K-SADS (current) } \\
\hline Depression & $4(7.7)$ & $8(28.6)$ & - & $0.03 *$ \\
\hline Anxiety disorder & $18(34.6)$ & $7(25.0)$ & - & Ns \\
\hline Disruptive behavioral disorder & $10(19,2)$ & $8(28,6)$ & - & Ns \\
\hline Elimination disorder & $1(1.9)$ & $11(39.3)$ & - & $0.00004 *$ \\
\hline Other & $3(5.8)$ & $4(14.3)$ & - & Ns \\
\hline \multicolumn{5}{|c|}{$\begin{array}{l}\text { DM: Type } 1 \text { diabetes mellitus, PG: Group with psychiatric disease, HC: Healthy controls, }{ }^{\#} \text { : } \\
\text { One-way ANOVA F=3.9; } \mathrm{p}=0.02 \text {, post hoc Scheffe test } \mathrm{HC}>\mathrm{DM}(\mathrm{p}=0.04),{ }^{\# \#}: \mathrm{F}=9.1 ; \mathrm{p}=0.00 \\
\text { post hoc Scheffe test HC>PG (p=0.00), DM }>\mathrm{PG}(\mathrm{p}=0.005),{ }^{\# \#} \text { Schedule for affective } \\
\text { disorders and schizophrenia for school-age children present and lifetime version, Ns: Non } \\
\text { significant. }\end{array}$} \\
\hline
\end{tabular}

Additionally, it was found that $\mathrm{HbA1C}$ increased with age $(\mathrm{r}=0.28 \mathrm{p}=0.04)$ but it was not correlated with the duration of the disease $(p>0.05)$. HbA1C levels of the diabetic children diagnosed with psychiatric problems were significantly higher compared to those without the diagnosis $(9.1 \pm 1.6$ and $8.1 \pm 1.3 ; \mathrm{t}=-2.3 ; \mathrm{df}=50 ; \mathrm{p}=0.024)$. In the patient group diagnosed with psychiatric diagnosis, no difference was found in terms of the 
frequency of hospitalization, participation to the treatment, diet and exercise compliance, treatment negligence and the frequency of the follow-ups (Table 4).

No significant correlation was detected between disease duration and HbAlc level, and self-concept and self-esteem ( $>0.05)$. In the healthy group, no significant difference was found between age and BMI and self-concept $(r=-0.31$ and $r=0.1$, respectively; $P>0.05)$ and self-esteem $(r=0.002$ and $r=-0.005$, respectively; $p>0.05)$. In children with psychiatric disease, it was found that self-esteem decreased with advancing age $(r=-0.4 ; p=0.03)$, but it was not related to self-concept $(\mathrm{r}=-0.37 ; \mathrm{p}>0.05)$. In this group, it was found that there was no significant correlation between BMI and self-concept $(\mathrm{r}=0.08)$ and self-esteem $(\mathrm{r}=-0.05 ; \mathrm{p}>0.05)$. In children with $\mathrm{DM}$, no significant correlation exists between age and BMI and self-concept $(r=-0.13$ and $r=-0.07$; respectively; $p>0.05)$ and self-esteem ( $r=-$ 0.05 and $\mathrm{r}=0.08$; respectively; $\mathrm{p}>0.05$ ).

Table 4. Disease characteristics in the children with DM with and without psychiatric disease.

\begin{tabular}{|c|c|c|c|}
\hline & & $\begin{array}{l}\text { Without psychiatric } \\
\text { diagnosis } n=21\end{array}$ & $\begin{array}{l}\text { With psychiatric } \\
\text { diagnosis } n=31\end{array}$ \\
\hline Disease duration (year) mean \pm sd & & $4.4 \pm 2.4$ & $4.3 \pm 2.2$ \\
\hline $\operatorname{HbA} 1 \mathrm{C}(\operatorname{mean} \pm \mathrm{sd}) *$ & & $8.1 \pm 1.3$ & $9.1 \pm 1.6$ \\
\hline Number of hospitalizations & & $1.4 \pm 0.6$ & $1.6 \pm 1.3$ \\
\hline \multirow[t]{2}{*}{ Patient's caregiver } & Him-/herself & $11(52.3)$ & $13(41.9)$ \\
\hline & Parents & $10(47.6)$ & $18(58.1)$ \\
\hline \multirow[t]{2}{*}{ Diet adherence } & Good & $13(61.9)$ & $11(35.5)$ \\
\hline & Bad & $8(38.1)$ & $20(64.5)$ \\
\hline \multirow[t]{2}{*}{ Adherence to exercise program } & Good & $18(85.7)$ & $26(83.9)$ \\
\hline & Bad & $3(14.3)$ & $5(16.1)$ \\
\hline \multirow[t]{2}{*}{ Treatment negligence } & Yes & $9(42.9)$ & $20(64.5)$ \\
\hline & No & $12(57.1)$ & $11(35.5)$ \\
\hline \multirow[t]{2}{*}{ Regularity of the follow-ups } & Regular & $19(90.5)$ & $28(90.3)$ \\
\hline & Irregular & $2(9.5)$ & $3(9.6)$ \\
\hline
\end{tabular}

\section{Discussion}

In this study, it was found that approximately two third (59.6\%) of the children with Type I DM had at least one psychiatric disorder and that $\mathrm{HbA1C}$ values were higher in diabetic children with psychiatric disorder compared to those without psychiatric disorder. This finding complies with the study results that demonstrated a positive correlation between the impairment of metabolic control with psychiatric problems and high $\mathrm{HbA} 1 \mathrm{C}$ values $[10,23]$. However, when the characteristics related to the disease and to the therapeutic compliance, such as the frequency of hospitalization, participation to disease care, adherence to diet and exercise program and the negligence of the therapy, were examined, it was seen that the presence of a psychiatric disease had no effect on these parameters. This finding does not comply with the results obtained from the study that reported that, in the children with DM, the presence of a psychiatric disease impaired the therapeutic compliance and demonstrated that they had a higher risk for hospitalization [5, 9]. Our result may be explained by some factors such as earlier age of the children participating to the study, on-going efficacy of the parents in disease-related issues and relatively shorter duration of the disease.

The incidence of elimination disorders (enuresis) was higher in the group with psychiatric disease compared to the patients with DM, a result that might be explained by inability to be coded due to the fact that enuresis could be related to general medical status in the diabetic group.

Another finding of our study was that the incidence of psychopathology was higher in the male children with DM compared to female diabetic children. This was thought to be related to the values such as greater strength and resistance attributed to male children in 
Turkish familial structure. While some studies conducted on the adolescents with Type I diabetes [23] found that gender was a specific risk factor for psychiatric problems, other investigators suggested that the male children with DM were more depressive after the age of 10 years compared to female diabetic children and the children with serious acute disease [15].

In our study, it was seen that the children with DM had a more negative self-concept compared to their healthy counterparts. This finding contradicts with the results obtained from the study conducted using PHCSCS, which showed that self-concept score was higher in the children with DM compared to healthy controls [24]. This result may be explained by the fact that the presence of a medical disease such as diabetes may affect the thoughts and attitudes of the individual towards him-/herself and may be interpreted as the perception of the disease as a weakness and the lack of self-satisfaction. It was found that, for self-esteem scores obtained from RSES, children from the group with psychiatric disorder had lower scores compared to both healthy counterparts and children with DM. In other words, self-esteem is negatively affected by the presence of psychiatric disorder rather than DM. In this area, negative effect mainly results from the impaired psychiatric health of the children.

In this study, no correlation was found between disease duration and HbAlc level, and scores of self-concept and self-esteem of the children with DM. The results obtained from the studies that investigated the correlation between self-esteem and adherence to diabetic therapy and HbA1C level were inconsistent [16, 25-28]. Our finding is consistent with the results of the study that demonstrated that self-esteem was independent from $\mathrm{HbA1C}$ level and diabetes duration [5]. In our study, we observed that HbA1C levels of the children with DM increased with age, suggesting the likelihood of glycemic control impairment toward the adolescence. In the studies performed in the children with DM, glycemic control was observed to have generally worsened during the adolescence [6].

In our study, it was seen that the percentage of describing the school achievement as "good" was lower in the children with DM and those with psychiatric disorder compared to healthy children and that the children with DM and those with psychiatric disorder similarly described their school achievements. In other words, school achievement is negatively affected by physical and psychiatric health problems.

In our study, we found that general relations of the children with DM and psychiatric disease were negatively affected compared to their healthy counterparts and that these relational problems were seen in wider range of areas in the children with DM. This finding may be explained by the impairment of communication skills due to long-term emotional and behavioural difficulties observed in previous studies conducted on the children with DM [25].

In conclusion; limitation and interference caused by chronic disease may impair family and social relations of the child and may form a basis for the psychiatric problems in the child. Psychiatric problems accompanying to the diabetes may negatively affect the course of the disease by impairing the therapeutic compliance of the child.

This study demonstrated that more than half of the diabetic children $(59.6 \%)$ had at least one psychiatric disorder, resulting to an elevated $\mathrm{HbA1C}$ value. These results may suggest that in diabetic children, mental problems could adversely affect the treatment for the disease and might lead to complications in long-term period. Therefore, psychiatric evaluation and monitoring of these children play an important role in the early detection of the mental problems. In our study, as the patients without diabetic complication, who were regularly followed-up in general, were more numerous, the studies with larger sample are warranted in order to both generalize and examine the correlation between self-esteem, mental problems and diabetes. 


\section{References}

1) Saka N, Neyzi O, Ertuğrul T. Endokrin sistem ve hastalıkları, Diabetes Mellitus. Pediatri 2, İstanbul, Nobel Tip 2002; 1306-21.

2) National Istitute of Diabetes and Digestive and Kidney Diseases (NIDDK). Diabetes in America. Bethesda, MD: NIH. Publication 2002; 02-3892.

3) American Diabetes Association. Standarts of medical care in diabetes-2007. Diabetes Care 2007; 30: 40-1.

4) Anderson BJ, Vangsness L, Connell A, Butler D, Goebel-Fabbri A, Laffel LMB. Family conflict, anderence, and glycaemic control in youth with short duration Type 1 diabetes. Diabetic Medicine 2002; 19: 635-42.

5) Gardner N. Emotional and behavioural difficulties in children with diabetes: A controlled comparison with sibling and peers. Child: Care, Health and Development 1998; 24: 115-28.

6) Northam EA, Matthews LK, Anderson PJ, Cameron FJ, Werther GA. Psychiatric morbidity and health outcome in Type 1 diabetes: Perspectives from a prospective longitudinal study. Diabet Medicine 2005; 22: 152-7.

7) Dantzer C, Swendsen J, Maurice-Tison S, Salamon R. Anxiety and depression in juvenile diabetes: a critical review. Clin Psychol Rev 203; 23: 787-800.

8) Grey M, Cameron M, Lipman TH, Thurber FW. Psychosocial status of children with diabetes in the first 2 years after diagnosis. Diabetes Care 1995; 18: 1330-6.

9) Lustman P, Griffith L, Clouse R. Psychiatric illness in diabetes mellitus. Relationship to symptoms and glucose control. J Nerv Ment Dis 1986; 174: 736-42

10) Kovacs M, Mukerji P, Iyengar S, Drash A. Psychiatric disorder and metabolic control among youts with IDDM. A longitudinal study. Diabetes Care 1996; 19: 318-23.

11) Ann G, M Alison S, J David B. Emotional, behavioural, and educational disorders in diabetic children. Archives of Disease in Childhood, 1980; 55: 371-5.

12) Ölçer S, Fiş NP, Berkem M, Karadağ B. Astımlı Çocukların Benlik Saygıları ve Annelerinin Duygu Dışavurum Düzeylerinin Değerlendirilmesi. Türk Pediatri Arşivi Dergisi 2010; 45: 144-9.

13) Murray MA, Rydall AC. Relationship of self-efficacy and bingeing to adherence to diabetes regimen among adolescents. Diabetes Care 1992; 15: 90-4.

14) Rosenberg M. Society and the adolescent self-image. New Jersey: Princeton University Press 1965.

15) Bednar R, Wells MG, Peterson SR. Self-esteem: Paradoxes and innovations in clinical theory and practice. Washington, DC: American Psychological Association 1989.

16) Jacobson AM, Hauser ST, Willett JB, Wolfsdorf JI, Duorak R, Herman L, deGroot M. Psychological adjustment to IDDM: 10-year follow-upof an onset cohort of child and adolescent patients. Diabetes Care 1997; 20: 811-8.

17) Piers EV, Harris DB, Herzberg DS. Piers-Harris Children's Self Concept Scale (Piers-Harris 2), 2nd edn. Los Angeles: Western Psychological Services 1984.

18) Öner N. Piers-Harris'in Çocuklarda Öz-Kavramı Ölçeği El Kitabı. Ankara: Türk Psikologlar Derneği 1996; 1.

19) Çataklı M. Transliteral equivalence and reliabilty of the Turkish version of the Piers-Harris Children's Self-Concept Scale. Yayınlanmamış Yüksek Lisans Tezi. Boğaziçi Üiversitesi, Sosyal Bilimler Enstitüsü 1985.

20) Çuhadaroğlu F. Adölesanlarda benlik saygısı. Hacettepe Üniversitesi Tip Fak, Psikiyatri ABD Yayımlanmamış Uzmanlık Tezi, Ankara 1986.

21) Kaufman J, Birmaher B, Brent D. Schedule for affective disorders and schizophrenia for school-age children-present and lifetime version (K-SADS-PL): initial reliability and validity data. J Am Acad Child Adolesc Psychiatry 1997; 36: 980-8. 
22) Gökler B, Ünal F, Pehlivantürk B. Okul çağı çocukları için duygulanım bozuklukları ve şizofreni görüşme çizelgesi-şimdi ve yaşam boyu şekli-Türkçe uyarlamasının geçerlik ve güvenirliği. Çocuk veGençlik Ruh Sağlığı Dergisi 2004; 11: 109-16.

23) Blanz BJ, Rensch-Rieemann BS, Fritz-Sigmound DI, Schmidt MH. IDDM is a risk factor for adolescent psychiatric disorders. Diabetes Care 1993; 16: 1579-87.

24) Ho J, Lee A, Kaminsky L, Wirrell E. Self-concept, attitude toward illness and family functioning in adolescents with Type 1 diabetes. Paediatr Child Health 2008; 13: 600-4.

25) Burch H. Physiologic and psychological inter-relationships in diabetes in children. Psychosomatic Medicine, II 1949; 200-10.

26) Holmes C, Chen R, Streisand R, Marschall D, Souter S, Swift E, Peterson C. Predictors of youth diabetes care behaviors and metabolic control: A structural equation modeling approach. Journal of Pediatric Psychology 2006; 31: 770-84.

27) Jacobson AM, Hauser ST, Wolfsdorf JI, Houlihan J, Milley JE, Herskowitz RD, Wertlieb D \& Watt E. Psychologic predictors of compliance in children with recent onset of diabetes mellitus. Journal of Pediatrics 1987; 110: 805-11.

28) Kovacs M, Godston D, Obrosky D, Iyengar S. Prevalence and predictors of pervasive non-compliance with medical treatment among youths with insulindependent diabetes mellitus. J Am Acad Child Adolesc Psychiatry 1992; 31: 11129.

29) Ryan C, Longstreet C, Morrow L. The effects of diabetes mellitus on the school attendance and school achievement of adolescents. Child Care Health Dev 1985; 11: $229-40$. 